\title{
Use of Parametric 3D Modelling - Tying Parameter Values to Spreadsheets at Designing Molds for Plastic Injection
}

\begin{abstract}
Michal Fabian ${ }^{1}$, Róbert Boslai ${ }^{1}$, Peter Ižol ${ }^{1}$, Jaroslava Janeková ${ }^{1}$, Jana Fabianová ${ }^{2}$, Gabriel Fedorko ${ }^{2}$ Pavol Božek $^{3}$ ${ }^{1}$ Faculty of Mechanical Engineering, Technical University of Košice, Letná 9, Košice, 040 01, Slovakia, michal.fabian@tuke.sk, robert.boslai@gmail.com, peter.izol@tuke.sk,jaroslava.janekova@tuke.sk

${ }^{2}$ Faculty of Mining, Ecology, Process Control and Geotechnology, Technical University of Košice, Park Komenského 14, Košice, 040 01, Slovakia, jana.fabianovauke.sk, gabriel.fedorko@tuke.sk

${ }^{3}$ Faculty of Materials Science and Technology in Trnava, Slovak University of Technology in Bratislava, Paulínska 16, Trnava, 917 24, Slovakia, pavol.bozek@stuba.sk
\end{abstract}

The current mechanical engineering is inconceivable without the implementation of CAx systems in design and manufacturing process of individual components. The automotive industry is a clear evidence of how CAx systems affect the innovation cycle of its product - a car. The innovation cycle in automotive was reduced from 8-12 years to the current 4-6 years. Even in this short interval automakers make some small design modifications called a facelift. Development in the automotive industry, therefore, is closely related to news and functionality CAx systems. CAD systems at the turn of the millennium are characterized as parametric graphic systems with a history tree of product creation. Parametric design implemented into CAD systems makes the model variable and open to rapid change management. The history tree in turn enables rapid editing and modification of forming or editing functions.

Keywords: CAD, 3D, parametric modeling, mold

\section{Acknoledgement}

The article was prepared with the support of grant project VEGA 1/0085/12, VEGA 1/0922/12, VEGA, VEGA 1/0500/12, KEGA 004TUKE-4/2013, project APVV SK-CZ-2013-0169 and OPVaV-2012/2.2/08-RO code ITMS 26220220182.

\section{References}

[1] ANDERL, R., MENDGEN, R. (1996). Modelling with constraints: theoretical foundation and application. In: Computer-Aided Design, Vol. 28, No. 3, pp. 155-168.

[2] BODEIN, Y., ROSE, B., CAILLAUD, E. (2014). Explicit reference modeling methodology in parametric CAD system. In: Computers in Industry, Vol. 65, No. 1, pp. 136-147.

[3] BETTIG, B., SHAH, J. (2001). Derivation of a standard set of geometric constraints for parametric modeling and data exchange. In: Computer-Aided Design, Vol. 33, No. 1, pp. 17-33.

[4] Naranje, V., Kumar, S. (2014) A knowledge based system for automated design of deep drawing die for axisymmetric parts. In: Expert Systems with Applications, Vol. 41, No. 4 PART 1, pp. 1419-1431.

[5] CHAN, I. W. M., PINFOLD, M., KWONG, C. K.., SZETO, W. H. (2014) Automation and optimisation of Family Mould Cavity and Runner Layout Design (FMCRLD) using genetic algorithms and mould layout design grammars. In: CAD Computer Aided Design, vol. 47, pp. 118-133.

[6] NARANJE, V., KUMAR, S. (2013). An intelligent CAD system for automatic modelling of deep drawing die. In: International Journal of Computer Applications in Technology, vol. 48, no. 4, pp. 330-344.

[7] LEU, M. C., Elmaraghy, H. A., NEE, A. Y. C., ONG, S. K.., LANZETTA, M., PUTZ, M., ZHU, W., BERNARD, A. (2013). CAD model based virtual assembly simulation, planning and training. In: CIRP Annals Manufacturing Technology, vol. 62, no. 2, pp. 799-822.

[8] ALTAN, T., LILLY, B., YEN, Y. C. (2001). Manufacturing of Dies and Molds. In: CIRP Annals - Manufacturing Technology, vol. 50, no. 2, pp. 404-422.

[9] FABIAN, M., SPIŠÁK, E., ŠEMINSKÝ, J., DOVICA, M., IŽOL, P. (2010). CAM parameters setup and milled concave and covex surface quality. In: Metalurgija, no. 2, pp. 181-185.

[10] GROOVER, M. P. (2010). Fundamentals of Modern Manufacturing: Materials: Processes, and Systems. John Wiley \& Sons, New York. 
[11] CHANG, C. H., MELKANOFF, M. A. (1989). NC machine programming and software design. Prentice Hall, New York.

[12] MICHALIK, P., ZAJAC, J., DUPLÁK, J., PIVOVARNÍK, A. (2012). CAM Software Products for Creation of Program for CNC Machining. In: Future Communication, Computing, Control and Management, vol. 1, pp. 421425.

[13] POKORNÝ, P., S̆IMNA, V. (2012). The proposal of a system for determining the characteristics of modeled surfaces. In: Tehnicki Vjesnik, vol. 19, pp. 197-199.

[14] SEMINSKY, J. (2013). Present Trends in Designing of Technical Systems. In: APPLIED MECHANICS AND MATERIALS, vol. 460, pp. 73-80.

[15] DANESHJO, N., KORBA, P., ELDOJATI, M. (2012). The CATIA design process, design and manufacture in aviation. In: Transfer of Inovation, vol. 23, no. 23, pp. 194-196.

[16] SPIŠÁK, E., KMEC, J., BREZINOVÁ, J., GUZANOVÁ, A., MAJERNÍKOVÁ, J. (2012) Materials for conventional and advanced technologies. pp. 317. TU Košice,

[17] GALANIS, D. E., MARKOPOUlOS, .N.I., GIANNAKOPOULOS, A.P., MANOLAKOS, I.D. (2013). Manufacturing of Femoral Heads from Ti-6Al-4V Alloy with High Speed Machining: 3D Finite Element Modelling and Experimental Validation. In: Manufacturing Technology, vol. 13, no. 4, pp. 437-444.

[18] MADL, J. (2012) Surface Properties in Precise and Hard Machining. In: Manufacturing Technology, vol. 12, no. 13, pp. 158-166.

[19] Jersák, L., Vrkoslavová, J. (2013). The Influence of Process Fluids on the Properties of the Surface Layer of Machined Components. In: Manufacturing Technology, vol. 13, no. 4, pp. 466-473.

[20] We have tried, as produced car. In: Auto Moto. [Online]. Available: <http://automoto.cas.sk/galeria/11711/vyskusali-sme-si-ako-sa-vyraba-auto?foto $=10>$ [Accessed: 19-Jun-2014]. 